\title{
Students' Perception On Language Style Used By English Lecturers In The Classroom
}

\author{
Ridianto \& Dodi Efwan. STKIP Yayasan Abdi Pendidikan Payakumbuh \\ ridianto@stkipabdi.ac.id \& ridianto1@gmail.com
}

\begin{abstract}
Abstrak
Gaya bahasa merupakan variasi dari bahasa yang di gunakan penutur berdasarkan situasi. Ada lima tipe gaya bahasa yaitu frozen, formal, consultative, casual dan intimate. Di dalam dunia pembelajaran, khususnya di perguruan tinggi, gaya bahasa yang di gunakan oleh seorang dosen merupakan salah satu faktor penentu keberhasilan mahasiswa. Namun faktor penentu keberhasilan seorang mahasiswa dalam belajar tidak hanya dapat dilihat dari gaya bahasa seorang dosen tetapi juga dari persepsi para mahasiswa. Karena hal ini lah penulis tertarik untuk menganalisa persepsi para mahasiswa terhadap gaya bahasa yang di gunakan oleh seorang dosen di dalam kelas di STKIP Abdi Pendidikan Payakumbuh. Penelitian ini adalah penelitian descriptif dengan menggunakan metode qualitatif yang mana populasi nya adalah mahasiswa tahun keempat jurusan pendidikan bahasa Inggris STKIP Abdi Pendidikan Payakumbuh tahun ajaran 2015/2016. Partisipan dipilih dengan menggunakan purposive sampling, sedangkan instrument dalam penelitian ini adalah questionnaire. Hasil penelitian ini secara umum adalah mahasiswa mempunyai persepsi yang cukup bagus $(832,4)$ terhadap gaya bahasa yang di gunakan dosen di dalam kelas dengan skor tertinggi di gaya konsultatif yaitu 1274 dan skor terendah di gaya intim yaitu 369.
\end{abstract}

Key words: Language. Language Style, Perception.

\section{INTRODUCTION}

In making language, there are several aspects that influence the use of it, one of them is style. According to Richard and Schmidt (2002:503) "style is alternative ways of speaking within a community, often ranging from more colloquial to more formal". As quote from Joos, Payne (2012:9) dispart style into five types they are: frozen, formal, consultative, casual and intimate.

As quoted from Joos in Haryanto (2001:105) in Romadlon, Payne (2012:9), Mesthrie et al (2004:93). There are several types of style, as follows.

\section{Frozen Style}

This style also called by hyper-formal style. It is a style used commonly for prose writing or for speech. It also used when we talk to strangers (Haryanto, 2001: 105). The characteristic of this style has lacks intonation, usually is the use of formal and polite language. Frozen language is always same and never change. For example: Lord's prayer, constitutional, etc.

The examples are:

a. On this occasion I desire to preach on the title......

b. Farewell and Godspeed.

2. Formal Style

Formal style usually is used in formal situation and uses formal language. Formal style is used by people who still have a distance between them (speaker and listener). A speaker usually avoids repetition or another term which tends to be a casual term and used in a discussion or a meeting (Haryanto, 2001:105). The 
characteristic this style has complete sentences and specific word choice, also marker of formal English style includes whom, may I, for the purpose of and so on.

Here are the examples:

a. Mrs. William, would you like to have a sit first before you deliver your speech?

b. I would like to introduce myself to you.

\section{Consultative Style}

Consultative style is used in business or in discussing something. A speaker who uses this style usually does not plan what he or she wants to say (Haryanto, 2001:106). Thus, there is a big possibility to make mistakes in speaking, such as word repetition or diction which cannot be avoided. In consultative, pronunciation is explicit, word choice is careful, sentence structure is complete and also markers of rapport like hmm, yes, I know.

Some of the examples are:

a. Excuse me, I think it's really important for me to add about the topic that we discuss.

b. Actually, we have the same views about this problem. So, why don't you joint with us?

\section{Casual Style}

Casual style is a style used in informal (casual) situation and using informal language. The relationship between speaker and hearer is close, so they usually use words or term repetition and frequently use ellipse sentences (Haryanto, 2001:105). In this style, word choice general and not specific, also sentence syntax often incomplete.

The examples are:

a. What makes you say that?

b. That's bullshit...!!!!

\section{Intimate Style}

Intimate style manifests extreme structural simplicity. This type of style has characteristic that its common use of personal language codes and it is only for certain group. It occurs in the certain community which has its own language style (Haryanto, 2001:106). Intimate style represents lexical form without grammatical structure and only partial phonology structure. Intonation is more important than wording or grammar.

Here are the examples:

a. Jesus Chris...! => Oh my God

b. Damn hot $=>$ Hot

In educational field, especially in university, language style that used by lecturer is one of important role for success of the students. However, factors that influence success of students in learning English, not only can be seen from language style that used by lecturer but also from perception that have by students.

The students that have good perception to their lecturer will make them more serious in learning English and automatically can improve their knowledge. In the opposite, students that have bad perception to the lecturer will cause the students uninspired in learning English.

According to Noe and Evan (2002:2) "perception is a process whereby the brain, or functionally dedicated subsystem of the brain, builds up representations of relevant features of the environment on the basis of information encoded by the sensory receptors".

\section{METHODOLOGY}

Descriptive qualitative research was used in this research as a way to get information about students' perception on language style used by lecturer in the classroom. Based on the 
educational research book, Gay and Arisian (2000:275) states that A descriptive study determines and describes the way thing are. Descriptive research is some detail for two major reasons. First, a high percentage of research studies are descriptive in nature. Second, the descriptive method is useful investigating a variety of educational problems and issues. Descriptive data are usually collected by observation, interview, telephone and questionnaire.

The students who study in STKIP Abdi Pendidikan in 2015/2016 academic year and who are studying in the eight semesters be participants in this research. They were totally about 68 students from two classes. There were 36 students from class A and 32 students from class B. In this research, the participants were taken by using purposive sampling. It is B class.

The researcher used questionnaires to see perception of students about language style used by lecturer in the classroom with the type of questionnaire is structured items (also called closed-ended items) because the participant's only checklist alternative answers. In this reaearch, peer debriefing was used by researcher to checking data trustworthiness. According to Gay, et.al (2012:393) states that peer debriefing is identify a critical friend, colleague, or significant other who is willing and able to help reflect on the research by listening, prompting and recording insights throughout the process. The questionnaire was used to get the data and has checked by the peoples that has professionals.

To analyze the data, researcher used the steps that are states by Gay; et.al (2000:239) states that there are some steps to analyze the qualitative data namely:

\section{Data managing}

The data organized and order to completeness of students answer from the questionnaire.

\section{Reading/Memoing}

The researcher read the answer of students from the questionnaire, in other to understand the students' answer.

3. Classifying

The researcher classified students' perception into five indicators of language style that used by lecturer in the classroom. They are; frozen style, formal style, consultative style, casual style and intimate style.

To analyze the percentage of students' respond for each indicator, the researcher used formula by sudijono, (2010:43):

$$
\mathrm{P}=\frac{f}{N} \times 100 \%
$$

$\mathrm{f}=$ Frequency of students' responds

$\mathrm{N}=$ number students' cases/total respondents

$\mathrm{P}=$ percentage of each category

4. Interpreting

According to Gay (2000:250) "data interpretation is based heavily on the connection, common aspect and linkages among the data, specially the identified categories and patterns". The researcher interpreted the data into general conclusion and understanding. To interprenting the data, the researcher used formula that suggest by Sudjono (2010:52) as follow:

$$
\begin{gathered}
\mathrm{R}=\mathrm{H}-\mathrm{L}+1 \\
\frac{R}{i}
\end{gathered}
$$


Where:

$$
\begin{aligned}
& \mathrm{R}=\text { Range } \\
& \mathrm{H}=\text { Highest } \text { Score } \\
& \mathrm{L}=\text { Lowest } \text { Score } \\
& 1 \text { = Constant Number } \\
& \mathrm{i}=\text { Class Interval }
\end{aligned}
$$

\section{Writing report}

Writing of the report to describe the research finding is the final process in qualitative research Gay (2000:253). The finally the researcher wrote the report.

\section{FINDING AND DISCUSSION}

The researcher found that the students have good enough perception on language style used by lecturer in the classroom with the average score was 832,4. For each indicator, the researcher found several findings. There were as follow:

First, the students have very good perception on consultative style used by lecturer in the classroom with the score was 1274. The researcher assumes that consultative style that used by lecturer in the classroom causing the students more enthusiasm in process of learning because this style makes interaction between the lecturer and the students. Chaer and Agustina (2010:71) say that this style is language style that the most operational. So, more of students like if this style used by lecturer in the classroom.

Second, the students have very good perception on formal style used by lecturer in the classroom with the score was 1105 . It is probably because in formal style, the lecturer use explicit pronunciation, clattering intonation and then information that is given by lecturer was receivable well by the students. Although the information was given to one student in the classroom, by using this formal style, the other students can receive the information. Chair and Agustina (2010:71) implied that the formal style was use in formal situation, was not in interface which was emphasize on transmition of information.

Third, the students have good enough perception on casual style used by lecturer in the classroom with the score was 734 . The researcher assumes that casual style that used by lecturer can cause shrinkage of stress of students in process of learning so that information and explanation that is given by lecturer can be understood by students.

Fourth, the students have less good perception on frozen style used by lecturer in the classroom with the score was 630 . The researcher assumes that frozen style can makes the students bored to hear explanation that is given by lecturer because this style is monotonous. According to Chaer and Agustina (2010:71), Frozen style is very formal style that used in formal ceremony such as sermon in the mosque.

The last, the students has bad perception on intimate style used by lecturer in the classroom with the score was 369 . The researcher assumes that this style unsuitable used in the classroom because the relation between the speaker and listener is to close and only them that understand what they said so that if the lecturer use intimate style in the classroom causing the information that is given by lecturer do not understood by all of student in the classroom. According to Chaer and Agustina (2010:71), Intimate style usually used when the relation with speaker and listener has intimate like family and friend. 


\section{CONCLUSION}

This research has purpose to see perception of student about language style used by lecturer in the classroom. The participant of this research was class B in English program in fourth grader at STKIP Abdi Pendidikan Payakumbuh in 2015/2016 academic year. The quistionnaires had used to see about students' perception on languge style used by lecturer in the classroom. The result of this reseach was the student has good enough perception about language style used by lecturer in the classroom with the higest score in consultatie style used by lecturer in the classroom and the lowest score in intimate style used by lecturer in the classroom.

\section{SUGGESTIONS}

Based on research findings, the researcher wants to offer some suggestions for lecturer, students and the next researcher. The suggestions as follow:

1. Lecturer

The researcher hopes the lecturer more selective to choose the kind of language style that used in the classroom.

2. Students

The researcher hopes that the students more seriously in learning although the kind of language style used by each lecturer are different.

3. Next researcher

The researcher hopes that this research can give information to next researcher about students' perception on language style used by lecturer in the classroom. 


\section{REFERENCES}

Broderick, John P. Anonymous. The five clocks of Martin joos: Why they keep on ticking. Old dominion Uneversity. ( published Thesis )

Chaer and Agustina.2010. Sosiolinguistik: Perkenalan Awal. PT. Rineka Cipta, Jakarta

Gay, L.R and Airasian, Peter.2000. Educational Research: Competencies for Analysis and Applications. United State of America: Mc Millan Publishing Company.

Gay, L.R et.al.2012. Educational Research: Competencies for Analysis and Applications. United State of America: Pearson Education.

Haryanto, Yan. 2001. Sociolinguistics. Jakarta: Universitas Terbuka.

Mesthrie, Rajend et. al.2004. Introducing Sosiolinguistics. Edinburgh University Press.

Noe, Alva and Evan, Thompson. 2002. Vision and Mind: Selected Reading in the Philosophy of Perception. United States: The MIT Press.

Payne, Ph.D. Ruby K. 2012. A framework for Understanding Poverty. Aha! Process, Inc.

Richard, C. Jack and Schmidt Richard. 2002. Longman Dictionary of Language teaching and applied Linguistic. Fakenham, Norfolk: Fakenham Photosetting.

Romadlon, Farid Noor. Anonymous. Using Casual Style to Engage Students' Speaking Motivation for English Young Learners. Teylin 2: From policy to classroom.

Sudijono, Anas. 2010. Pengantar Statistik Pendidikan. Jakarta: PT Rajawali Pers.

Wardhaugh, Ronald and Fuller Janet M.2015. An Introduction to Sosiolinguistics. Willey Blackwell 